\title{
Dietary restriction improved feed efficiency of inefficient lactating cows
}

\author{
Y. A. Ben Meir, ${ }^{1,2}$ M. Nikbachat, ${ }^{1}$ Y. Portnik, ${ }^{1}$ S. Jacoby,,${ }^{1}$ H. Levit, ${ }^{2,3}$ D. Bikel,,${ }^{1,2,4}$ G. Adin,,${ }^{4}$ U. Moallem, ${ }^{1}$ \\ J. Miron, ${ }^{1}$ S. J. Mabjeesh, ${ }^{2}$ and I. Halachmi ${ }^{3 *}$ \\ ${ }^{1}$ Department of Ruminant Science, Institute of Animal Science, Agricultural Research Organization, Rishon Lezion 7528809, Israel \\ ${ }^{2}$ Department of Animal Sciences, The Robert H. Smith Faculty of Agriculture, Food, and Environment, The Hebrew University of Jerusalem, \\ Rehovot, Israel 7610001 \\ ${ }^{3}$ Precision Livestock Farming Laboratory, Institute of Agricultural Engineering, Agricultural Research Organization, Rishon Lezion 7528809 , Israel \\ ${ }^{4}$ Department of Animal Production, Extension Service, Ministry of Agriculture, Rishon Lezion 7528809, Israel
}

\section{ABSTRACT}

The aim of this study was to reduce voluntary dry matter intake (DMI) to increase feeding efficiency of preclassified inefficient (INE) dairy cows through restricted feeding. We studied the effects of dietary restriction on eating behavior, milk and energy-corrected milk (ECM) production, in vivo digestibility, energy balance, and measures of feed efficiency [residual feed intake (RFI) and ECM/DMI]. Before the experiment, 12 pairs of cows were classified as INE. The 2 dietary treatments consisted of ad libitum feeding versus restricted feeding of the same total mixed ration containing $36.5 \%$ roughage. Inefficient cows fed the restricted total mixed ration had a shorter eating time and lower meal and visit frequency, but a similar rate of eating, meal size, and meal duration compared with INE cows fed ad libitum. Compared with the INE cows fed ad libitum, restricted INE cows had $12.8 \%$ lower intake, their dry matter and neutral detergent fiber digestibility remained similar, and their ECM yield was 5.3\% lower. Feed efficiency, measured as RFI, ECM/DMI, and net energy retained divided by digestible energy intake, was improved in the restricted INE cows as compared with the ad libitum cows. Our results show that moderate DMI restriction has the potential to improve feed efficiency of preclassified INE cows.

Key words: feed efficiency, residual feed intake, feed restriction

\section{INTRODUCTION}

The dairy cattle industry has improved in recent decades, with increasing milk yield and milk components. Increased DMI encourages milk production (Friggens et al., 1995), but high-yielding cows differ widely in

Received January 17, 2019.

Accepted May 7, 2019.

*Corresponding author: halachmi@volcani.agri.gov.il their feed utilization. Systems for classifying efficient (E) and inefficient (INE) cows in commercial farms are under development (Bloch at al., 2019; Halachmi et al., 2019). Beyond the genetic merit of such systems, farm application depends on dietary management-how to fit DMI to a known feed efficiency of the target animal. Differences among cows in efficiency are mostly influenced by DMI rather than milk production and BW change (Potts et al., 2015; Xi et al., 2016). Recently, Ben Meir et al. (2018) reported that INE cows differ from $\mathrm{E}$ cows fed the same (31.4\% roughage) TMR by having a DMI that is $25 \%$ higher owing to a $23 \%$ faster eating rate and $23 \%$ larger meal size, although ECM yield of INE and E cows remained similar. Ben Meir et al. (2018) explained these findings by highlighting that the INE cows consumed DM and digestible energy (DE) beyond their energy needs, resulting in excess energy losses and reduced feed efficiency, compared with the slower-eating E cows.

The common practice at modern commercial farms in Israel is to feed a single TMR for ad libitum intake, and milk the cows 3 times per day. A low roughage (31-37\% of DM) TMR is commonly fed ad libitum to all lactating cows in the Israeli herd, with DMI ranged from 25 to $33 \mathrm{~kg} / \mathrm{d}$ for cows yielding $>40 \mathrm{~kg}$ of milk/d (Ben Meir et al., 2018). These practices promote overeating among INE cows and contribute to their inefficiency. Therefore, the use of moderate feed restriction is suggested for improving the efficiency of preclassified INE cows. Recently, Cavallini et al. (2018) demonstrated that $3.6 \%$ feed restriction of DMI to lactating cows fed a low-roughage TMR (34.5\% of DM) improved feed efficiency measured as ECM/DMI. Additional studies (Wheelock et al., 2010; Ferraretto et al., 2014) also showed that intake restrictions of 7.6 and $25 \%$ for dairy cows fed TMR containing $50 \%$ roughage led to improvements in ECM/DMI. However, studies are lacking with regard to the effects of feed restriction on eating behavior, residual feed intake (RFI), and energy balance of preclassified INE cows. 
Therefore, in this study, we aimed to measure the effects of moderate (12.8\%) restriction of ad libitum intake in 12 pairs of preclassified INE cows (RFI $>3.0$ $\mathrm{kg}$ of DM) fed a low-roughage TMR (36.5\% of DM) on eating behavior, rumination, digestibility, milk production, and efficiency in terms of RFI, ECM/DMI, and the ratio total energy retained divided by the digestible energy intake.

\section{MATERIALS AND METHODS}

\section{Ethics}

The experiment was approved by the ARO institutional ethics committee, according to regulations regarding protection of animals used for scientific purposes-Directive 2010/63/EU and Israeli law.

\section{Animals, Feeding Regimen, and Experimental Design}

During the spring of 2018, 24 multiparous lactating Holstein cows were selected for this study in Israel. Prior to the present study, the individual efficiency of each cow in the entire Agricultural Research Organization (ARO) dairy herd (220 cows) was estimated. Cows were fed a low-roughage TMR ad libitum, and the repeatability of efficiency and eating behavior traits in lactating cows were evaluated according to lactation trimester and between parities (Ben-Meir et al., 2019). Average RFI of ARO lactating cows was $1.5 \mathrm{~kg}$ of $\mathrm{DM} / \mathrm{d} ; 20 \%$ of the cows were efficient, as characterized by RFI $<0.5 \mathrm{~kg}$ of DM; and $20 \%$ were inefficient, as characterized by RFI $>3.0 \mathrm{~kg}$ of DM. Because the present study aimed to restrict DMI of INE cows, we selected 12 pairs of mid-lactation INE cows from the ARO herd with an average daily DMI of approximately $30 \mathrm{~kg}$. The INE cows $(\mathrm{n}=24)$ were adapted for $2 \mathrm{wk}$ to the barn and fed the experimental TMR (Table 1) for ad libitum intake ( $5 \%$ orts). Then, the 24 INE cows were paired and divided into 2 groups of 12 cows each with similar DIM, ECM yield, DMI, parity, ECM/DMI, and RFI (average $\pm \mathrm{SE}, 213 \pm 11.3 \mathrm{~d}, 38.4 \pm 0.90$ $\mathrm{kg} / \mathrm{d}, 29.8 \pm 0.90 \mathrm{~kg} / \mathrm{d}, 2.23 \pm 0.47,1.31 \pm 0.02$, and $3.92 \pm 0.27$, respectively). One group of 12 INE cows was fed the TMR ad libitum, and the second group of 12 INE cows was fed the restricted TMR. The restriction was calculated to be $13 \%$ less than the observed individual intake of the ad libitum adaptation period. Dietary ingredients and chemical composition of the TMR are shown in Table 1.

Cows were housed in the ARO experimental dairy barn (Rishon Lezion, Israel), which is equipped with an individual cow feed intake-recognition system (Halachmi et al., 1998). The system included 24 feeders, with an antenna at each feeder that recognized a sensor tied to a front leg of each cow. Thus, when a cow approached a predefined feeder, the system opened the feeder gate only for that specific animal. Each individual feeder was located on top of weighing balances. This experimental setup, described by Halachmi et al. (1998), recorded entry and exit time of each cow to its specific feeder, along with computerized online monitoring of how much feed was consumed. Because each cow had its unique feeder, hierarchy interruption among cows was minimized, and the system enabled detection of each visit to the feeder. Data collected included visit and meal frequency, visit duration, meal size and duration, distribution of diurnal eating during day and night times, eating rate, daily eating time, and daily feed intake. A visit was defined as eating at least $200 \mathrm{~g}$ DM within at least 5 min of staying in the feeder.

Table 1. Ingredients, chemical and structural composition, and in vitro digestibility of TMR

\begin{tabular}{lc}
\hline Item & TMR \\
\hline Ingredient, \% of TMR DM & \\
Corn grain, ground & 29.3 \\
Soybean meal & 2.0 \\
Corn silage & 20.9 \\
Wheat hay & 15.6 \\
Corn gluten feed & 8.9 \\
Rapeseed meal & 8.8 \\
Dried distillers grains & 8.0 \\
Whey concentrate & 3.4 \\
Ca-LCFA ${ }^{1}$ & 0.6 \\
Sodium bicarbonate & 0.7 \\
Calcium and sodium chloride & 0.7 \\
Calcium carbonate & 0.7 \\
Urea & 0.3 \\
Vitamins and trace minerals ${ }^{2}$ & 0.045 \\
Composition, \% \pm SE of TMR DM & \\
DM, \% of wet TMR & $65.1 \pm 0.51$ \\
OM & $92.3 \pm 0.02$ \\
CP & $16.5 \pm 0.87$ \\
Ether extract & $5.70 \pm 0.37$ \\
NDF & $29.0 \pm 0.51$ \\
Roughage NDF & $17.5 \pm 0.33$ \\
NFC & $41.1 \pm 0.65$ \\
peNDF & $8.6 \pm 0.29$ \\
Particle size & \\
>19 mm & $15.5 \pm 0.52$ \\
8-19 mm $<8$ mm & $14.0 \pm 0.37$ \\
In vitro DM digestibility & $70.5 \pm 2.42$ \\
Gross energy, Mcal/kg of DM & $76.3 \pm 1.02$ \\
\hline Calcim sats of long-chan faty aciss & $4.44 \pm 0.01$ \\
\hline
\end{tabular}

${ }^{1}$ Calcium salts of long-chain fatty acids.

${ }^{2}$ Mix containing (g/kg of mix DM): Zn, 24; Fe, 24; Cu, 12.8; Mn, 24; I, 1.44; Co, 0.32 ; Se, $0.32 ; 16 \mathrm{MIU}$ of vitamin $\mathrm{A} ; 3.2 \mathrm{MIU}$ of vitamin $\mathrm{D}_{3}$; and $48 \mathrm{kIU}$ of vitamin $\mathrm{E}$.

${ }^{3}$ peNDF $=$ physically effective NDF remaining above the 8-mm sieve. ${ }^{4}$ Based on bomb calorimeter results. 
When the interval between the end of one visit and the beginning of the next one was shorter than $28 \mathrm{~min}$, the visits were considered part of a single meal. Calculation of this critical interval time was based on methods and equations described previously (Tolkamp et al., 1998; DeVries et al., 2003).

In parallel with the individual cow feed intakerecognition system, DMI was recorded manually every day by weighing feed delivery minus orts. The resultant values were used for validating DMI measurement based on summarized daily visit sizes monitored by the computer. This double check ensured appropriate daily measurement of DMI, which is the key factor in determining efficiency. All cows were housed in a common shaded open barn as a single group and had free access to water. The TMR was delivered individually to each cow in its specific feeder (Table 1) once daily between 0900 and $1000 \mathrm{~h}$. The ad libitum group received the average of the last $5 \mathrm{~d}$ DMI plus $5 \%$. At the evening or morning milking, an additional $10 \%$ TMR was added to empty feeders to ensure ad libitum intake ( $5 \%$ orts). The restricted group received a constant amount calculated as $87 \%$ of DMI in the 2 -wk adaptation period. From this constant amount, $5 \mathrm{~kg}$ of TMR was spared for each cow, and redelivered during evening or morning milking to avoid prolonged lack of food leading to stress. Samples of TMR were taken daily from each individual feeder immediately after feeding, and orts of the ad libitum group were collected from each feeder before the next morning feeding. The daily TMR and orts samples were mixed and pooled weekly for each cow during the 5 wk of the experiment for determining DM content and structural and chemical composition of the TMR. Following the 2-wk adaptation period in the barn and during ad libitum feeding, cows were paired to the dietary treatments (restricted vs. ad libitum). The following $4 \mathrm{wk}$ were dedicated to daily monitoring of milk production and composition, DMI, free eating behavior (without tying or sampling the cow at the feeder), rumination time, lying time, and efficiency measured as RFI and ECM/DMI. Week 5 of the experiment was dedicated to rumen fluid sampling for $\mathrm{pH}$ measurement and fecal grab sampling for in vivo digestibility analysis.

This regimen was based on previous studies that showed that a 4-wk period of RFI or ECM/DMI data collection supports repeatable RFI estimations within lactation trimesters and across parities (Asher et al., 2014; Ben Meir et al., 2018, 2019).

\section{Milk Performance, BW Measurement, and Lying Time}

Cows were milked 3 times per day at 0500, 1300, and $2100 \mathrm{~h}$. Milk yield (kg) and fat, protein, and lac- tose contents of the milk were recorded daily for each cow by an automatic meter equipped with an online near-infrared spectrometer (Afilab, Afimilk Ltd., Kibbutz Afikim, Israel) as validated by Weller and Ezra (2016). Daily BW was recorded by an automatic walkover scale (Afimilk Ltd.), 3 times per day, when cows were exiting the milking parlor. The ADG of each cow was calculated as the difference between average BW at wk 2 of adaptation and average BW at wk 5 of the experimental period. Outliers' BW data in the range of 3 times SD below or above the weekly average were deleted from the daily and weekly average calculations. These measurements of BW changes were used to overcome the daily variation in BW caused by eating and drinking, as well as the influence of urine and fecal excretion (Shaani et al., 2016). Daily lying time for each cow, suggested by Drissler et al. (2005) to be an indicator of animal welfare, was recorded daily by an automatic meter located on each cow's pedometer tag (Afimilk Ltd.), as validated by Swartz et al. (2016).

\section{Rumination}

All cows were equipped with collar-mounted HRTags (SCR Engineers Ltd., Netanya, Israel) that monitored and transmitted rumination time (Schirmann et al., 2009). Rumination data were recorded daily during the 5-wk experiment by a special sensor that detected the rhythmic movement from rumination. Data were stored in 2-h blocks and wirelessly uploaded through the antenna to the computer at the milking parlor 3 times daily.

\section{In Vivo Digestibility}

In wk 5 of the study, $4 \mathrm{~d}$ were assigned for daily sampling of TMR, orts, and feces from each cow. Estimation of daily fecal excretion was based on indigestible NDF (iNDF) concentration in feces, refusals, and the TMR. Samples of the TMR and orts were dried $\left(60^{\circ} \mathrm{C}\right.$ for $48 \mathrm{~h}$ ) and ground to pass a 1-mm sieve (S-M-100; Retsch GmbH, Haan, Germany). Fecal grab samples were collected 3 times per day during the $4 \mathrm{~d}$ at 2 -h intervals around the clock and pooled for each cow, dried at $60^{\circ} \mathrm{C}$ for $48 \mathrm{~h}$ in a forced-air oven, and ground to pass a $1-\mathrm{mm}$ sieve. The ratio of $\mathrm{iNDF}$ in TMR to that in the feces is identical to the ratio of fecal DM to DMI for each cow, which is actually the reciprocal of in vivo DM digestibility according to the following equation (Adin et al., 2009): DM digestibility $=1-$ (TMR iNDF/fecal iNDF). The digestibility values of each chemical component [i.e., DM, CP, ether extract (EE), NDF, and NFC] were calculated for every cow using its proportion between intake minus orts and fe- 
cal output according to the equation presented in Adin et al. (2009).

\section{Rumen $\mathrm{pH}$}

In wk 5 of the study, all cows were sampled for rumen $\mathrm{pH}$ on 2 sequential days, twice per day: before feeding and $6 \mathrm{~h}$ postfeeding. This sampling routine was based on preliminary observations of maximal and minimal rumen $\mathrm{pH} 1 \mathrm{~h}$ prefeeding and $6 \mathrm{~h}$ postfeeding, respectively (Shaani et al., 2016). Rumen fluid ( $400 \mathrm{~mL}$ ) was collected from each cow via an esophageal metal-coated rubber pipe (2-m length, $15-\mathrm{mm}$ i.d.) connected to a vacuum pump. For each sample, to avoid saliva contamination, the vacuum pump was turned on only after the sampler pipe was inserted through the esophagus and placed in the approximate ventral portion of the rumen according to a premarked distance on the tube, and the first $200 \mathrm{~mL}$ of rumen fluid was discarded. Rumen $\mathrm{pH}$ values were immediately determined by a portable pH meter (PL 600, MRC, Netanya, Israel).

\section{Calculation of Feed Efficiency and Energy Balance}

The RFI of each cow was estimated as follows: measured DMI - predicted DMI. Predicted DMI was calculated according to the following equation (NRC, 2001): $\mathrm{DMI}=\left[(0.372 \times \mathrm{FCM})+\left(0.0968 \times \mathrm{BW}^{0.75}\right)\right]$ $\times \exp [0.192 \times(\mathrm{DIM} / 7+3.67)]$, where $4 \% \mathrm{FCM}=$ $0.4 \times$ milk yield $(\mathrm{kg} / \mathrm{d})+15 \times$ fat yield $(\mathrm{kg} / \mathrm{d})$. This method of RFI estimation was based on previous studies (Asher et al., 2014; Ben Meir et al., 2018, 2019) and enables other research groups to compare their efficiency results on the same predicted DMI basis (DMI estimation according to NRC 2001). Energy-corrected milk yield $(\mathrm{kg} / \mathrm{d}$, of standard milk containing $3.5 \%$ fat, $3.5 \%$ protein, and $5 \%$ lactose, with energy value of $0.714 \mathrm{Mcal} / \mathrm{kg}$ milk; NRC, 2001) was calculated as follows: milk yield $(\mathrm{kg} / \mathrm{d}) \times\{[0.3887 \times$ milk fat $(\%)]$ $+[0.2356 \times$ milk protein $(\%)]+[0.1653 \times$ milk lactose (\%)] $/ 3.1338$ (Moallem, 2016). Net energy in milk was calculated as $\mathrm{NE}_{\mathrm{L}}(\mathrm{Mcal} / \mathrm{d})=\mathrm{ECM} \mathrm{kg} / \mathrm{d} \times 0.714$ $\mathrm{Mcal} / \mathrm{kg}$. Net energy for maintenance was calculated as $\mathrm{NE}_{\mathrm{M}}(\mathrm{Mcal} / \mathrm{d})=0.08 \times \mathrm{BW}^{0.75}(\mathrm{NRC}, 2001)$. A veterinarian measured BCS of each cow at the beginning of the experimental period. Net energy captured in daily BW gain was calculated according to the BCS of each cow using data in Table 2.4 of NRC (2001). Total daily net energy retained $\left(\mathbf{N E}_{\mathbf{T}}\right)$ was calculated as $\mathrm{NE}_{\mathrm{L}}$ $+\mathrm{NE}_{\mathrm{M}}+\mathrm{NE}_{\mathrm{G}}$.

Digestible energy (DE Mcal $/ \mathrm{kg}$ DM) was calculated as follows: gross energy (GE) in TMR (Mcal $/ \mathrm{kg} \mathrm{DM}$ ) $-\mathrm{GE}$ in orts $(\mathrm{Mcal} / \mathrm{kg} \mathrm{DM}) \times \%$ orts $-\mathrm{GE}$ in feces $(\mathrm{Mcal} / \mathrm{kg} \mathrm{DM}) \times(1-$ in vivo DM digestibility $)$. Digest- ible energy intake $($ DEI, Mcal $/ \mathrm{d})=\mathrm{DE} \times$ DMI. Heat production (HP) and energy lost in urine, breathing, gases, and sweating were calculated as HP + energy loss $=\mathrm{DEI}-\mathrm{NE}_{\mathrm{T}}$.

\section{Sample Analyses}

Dry matter content of the TMR, orts, and fecal samples was determined by drying in a forced-air oven for $48 \mathrm{~h}$ at $60^{\circ} \mathrm{C}$. Chemical composition of the TMR, orts, and fecal samples was analyzed in dried samples ground to pass through a 1-mm sieve. Neutral detergent fiber was analyzed with heat-stable amylase and sodium sulfite according to the method of Van Soest et al. (1991) using the Ankom fiber analyzer (Ankom 220 Technology, Macedon, NY). Crude protein was determined according to the Kjeldahl method (procedure 14.068 in AOAC, 1990). Fat content in TMR, orts, and feces was determined by ether extraction in a Soxhlet apparatus for $24 \mathrm{~h}$ according to AOAC procedure 14.131 (AOAC, 1990). Organic matter content in TMR was determined after ashing dry samples at $550^{\circ} \mathrm{C}$ for $5 \mathrm{~h}$. Nonfiber carbohydrate was determined as follows: $\mathrm{OM}-\mathrm{NDF}-$ CP - EE (NRC, 2001).

Particle size distribution of TMR and orts was determined by a Penn State Particle Separator, with a 19-mm screen (long), an 8-mm screen (medium), and a pan (fine) (Lammers et al., 1996). Physically effective NDF (peNDF) was calculated according to the equation of Kononoff et al. (2003): peNDF (g/kg of DM) = (g of wet fraction from the $8-\mathrm{mm}+19-\mathrm{mm}$ sieves) $\times$ $\% \mathrm{DM}$ in separated fraction $\times \% \mathrm{NDF}$ in original $\mathrm{DM}$ sample/g of DM sample.

In vitro DM digestibility was analyzed in dried ground TMR samples according to the 2-stage technique of Tilley and Terry (1963), using rumen fluid obtained from 2 ruminally fistulated dry Holstein cows fed the same TMR (Table 1). In vitro analysis was performed on each weekly pooled TMR sample in 4 batch replicates. The 2 -stage in vitro digestibility technique of Tilley and Terry (1963) was also used to analyze the content of residual iNDF in the TMR, orts, and pooled fecal samples of each cow (Adin et al., 2009). Triplicate samples of TMR, orts, and pooled feces of each cow were pressed into 1-g pellets, and gross energy was measured using a bomb calorimeter (6100, Parr Instrument Company, Moline, IL) with benzoic acid used as a standard.

\section{Statistical Analyses}

For comparison between the restricted and the ad libitum INE groups, the following parameters were summarized by day: DMI, eating behavior traits, milk yield 
and components, ECM, RFI, ECM/DMI, rumination, rumination/kg DM, lying time, DEI, $\mathrm{NE}_{\mathrm{L}}, \mathrm{NE}_{\mathrm{M}}, \mathrm{NE}_{\mathrm{T}}$, $\mathrm{NE}_{\mathrm{T}} / \mathrm{DEI}, \mathrm{NE}_{\mathrm{L}} / \mathrm{DEI}$, and HP + energy loss. Data were analyzed using a mixed model $F$-test in JMP pro-14.0 software (SAS Institute Inc., 2016) with date, treatment, and treatment $\times$ date as fixed effects; animal (cow) as random effect; and residual repeated structure.

The following parameters were summarized by cow and comparisons of means between treatments analyzed using Student's $t$-test: ADG, in vivo digestibility traits, rumen $\mathrm{pH}, \mathrm{NE}_{\mathrm{G}}$, and DE. Average DIM, ECM production, and DMI of the 2 treatments groups within the 12 INE pairs were similar during the 2 -wk adaptation. Therefore, we did not use covariance corrections for initial DIM, ECM, and DMI of the other variables.

\section{RESULTS}

\section{Feed Restriction Effects on Eating Behavior and Production of INE Cows}

The feed restriction reduced daily DMI by $12.8 \%$ in the restricted INE cows compared with the ad libitum cows (Table 2). Milk yield of the restricted INE cows was $7.7 \%$ lower than that of the ad libitum cows (Table 2 ). However, because milk fat, protein, and lactose contents were higher in the restricted versus ad libitum INE cows, ECM yield of the restricted group was only $5.3 \%$ lower. Consequently, efficiency measured as RFI of the INE cows fed a restricted diet was lower and ECM/DMI was higher compared with the cows fed ad libitum.

The feed intake reduction was reflected in a $9.8 \%$ shorter daily eating time and a $9.5 \%$ decline in number of visits and meals in the restricted compared with the ad libitum INE cows (Table 2). However, eating rate, length of meal and visit, and frequency of meals and visits remained similar. The circadian distribution of DMI (Figure 1) of INE cows fed the 2 dietary treatments showed 5 major distinct waves of meals between 0500 to $2300 \mathrm{~h}$ and an additional flat meal wave during the night in accordance with average meal frequency data (Table 2). External events included 3 returns from milking and feed delivery at $0900 \mathrm{~h}$, which are marked with rectangles on the time line in Figure 1. The ad libitum INE cows consumed more feed than the restricted INE group in the period between evening and early morning, while restricted INE cows compensated for some of their lower intake after feed delivery (Figure 1). The restriction regimen for each cow, which included sparing of $5 \mathrm{~kg}$ at morning feeding and redelivering it at the evening or early morning, was reflected in similar diurnal eating distribution for both dietary groups of INE cows.

\section{Feed Restriction Effects on Digestibility, Rumen pH, Rumination, and Energy Balance of INE Cows}

In vivo digestibility of $\mathrm{DM}, \mathrm{OM}, \mathrm{NDF}$, and $\mathrm{CP}$ was similar for cows fed the restricted versus ad libitum TMR (Table 3); accordingly, DE per kilogram of DM was also similar. Average ruminal $\mathrm{pH}$ values at the morning prefeeding or $6 \mathrm{~h}$ post feeding were similar in the INE cows fed the 2 dietary regimens. Daily rumination time was slightly longer $(3 \%)$, but rumination time per kilogram of DMI was $9.8 \%$ shorter in the cows fed ad libitum versus cows fed restricted TMR. Lying time of cows fed the ad libitum diet was $7.3 \%$ longer than that of the restricted cows (Table 3).

Energy balance calculation (Table 4) for INE cows showed that DEI of the cows fed the restricted diet was $13.1 \%$ lower than that of the ad libitum group. The $\mathrm{NE}_{\mathrm{L}}$ captured in milk was larger in the cows fed the ad libitum diet, whereas $\mathrm{NE}_{\mathrm{M}}$ and $\mathrm{NE}_{\mathrm{G}}$ were similar for both treatments. Consequently, $\mathrm{NE}_{\mathrm{T}}$ used was $5.7 \%$ greater in the cows fed TMR ad libitum versus cows fed restricted TMR. As a result, energy efficiency, calculated as $\mathrm{NE}_{\mathrm{T}} / \mathrm{DEI}$, increased by $8.1 \%$ in the cows fed the restricted diet versus cows fed ad libitum. This superiority in energetic efficiency was mainly attributed to the $20.5 \%$ reduction in HP + energy loss of cows fed the restricted diet versus those fed ad libitum.

Table 2. Eating behavior, milk production, and efficiency of preclassified inefficient cows fed ad libitum versus cows fed restricted diet

\begin{tabular}{|c|c|c|c|}
\hline \multirow[b]{2}{*}{ Item $^{1}$} & \multicolumn{2}{|c|}{ Inefficient cows (means $\pm \mathrm{SE}$ ) } & \multirow[b]{2}{*}{$P$-value } \\
\hline & Restricted & Ad libitum & \\
\hline $\mathrm{N}$ & 12 & 12 & \\
\hline DMI, $\mathrm{kg} / \mathrm{d}$ & $26.5 \pm 0.16$ & $30.4 \pm 0.25$ & 0.01 \\
\hline $\mathrm{ECM}, \mathrm{kg} / \mathrm{d}$ & $35.7 \pm 0.36$ & $37.7 \pm 0.34$ & 0.01 \\
\hline RFI, kg/d & $-0.32 \pm 0.15$ & $3.54 \pm 0.24$ & 0.01 \\
\hline ECM/DMI & $1.35 \pm 0.01$ & $1.25 \pm 0.01$ & 0.01 \\
\hline Milk, $\mathrm{kg} / \mathrm{d}$ & $37.1 \pm 0.45$ & $40.2 \pm 0.35$ & 0.01 \\
\hline Milk fat, $\%$ & $3.72 \pm 0.03$ & $3.51 \pm 0.02$ & 0.01 \\
\hline Milk protein, $\%$ & $3.37 \pm 0.01$ & $3.30 \pm 0.01$ & 0.01 \\
\hline Milk lactose, \% & $4.87 \pm 0.01$ & $4.83 \pm 0.01$ & 0.01 \\
\hline $\mathrm{ADG}, \mathrm{kg} / \mathrm{d}$ & $0.80 \pm 0.03$ & $0.91 \pm 0.03$ & 0.64 \\
\hline $\mathrm{ET}, \min / \mathrm{d}$ & $170 \pm 2.57$ & $188 \pm 2.88$ & 0.01 \\
\hline $\mathrm{ER}, \mathrm{g}$ of $\mathrm{DM} / \mathrm{min}$ & $156 \pm 2.23$ & $161 \pm 3.02$ & 0.11 \\
\hline $\mathrm{Meal}^{2}$ frequency/d & $5.16 \pm 0.09$ & $5.73 \pm 0.09$ & 0.01 \\
\hline $\mathrm{Meal}^{2}$ size, $\mathrm{kg}$ of DM & $5.23 \pm 0.11$ & $5.30 \pm 0.11$ & 0.51 \\
\hline $\mathrm{Meal}^{2}$ duration, min & $36.7 \pm 0.71$ & $37.0 \pm 0.79$ & 0.77 \\
\hline Visit $^{3}$ frequency/d & $7.86 \pm 0.18$ & $8.69 \pm 0.22$ & 0.01 \\
\hline Visit $^{3}$ size, $\mathrm{kg}$ of DM & $3.67 \pm 0.09$ & $3.82 \pm 0.11$ & 0.29 \\
\hline Visit $^{3}$ duration, min & $23.3 \pm 0.60$ & $23.7 \pm 0.71$ & 0.73 \\
\hline
\end{tabular}

${ }^{1} \mathrm{ER}=$ eating rate; $\mathrm{ET}=$ eating time; $\mathrm{RFI}=$ residual feed intake.

${ }^{2} \mathrm{~A}$ meal is defined as the sum of close visits initiated less than $28 \mathrm{~min}$ after the end of the previous visit. Meal duration is calculated as sum of visits + intervals between visits within average meal.

${ }^{3} \mathrm{~A}$ visit is defined as eating at least $200 \mathrm{~g}$ of DM within at least 5 min. 


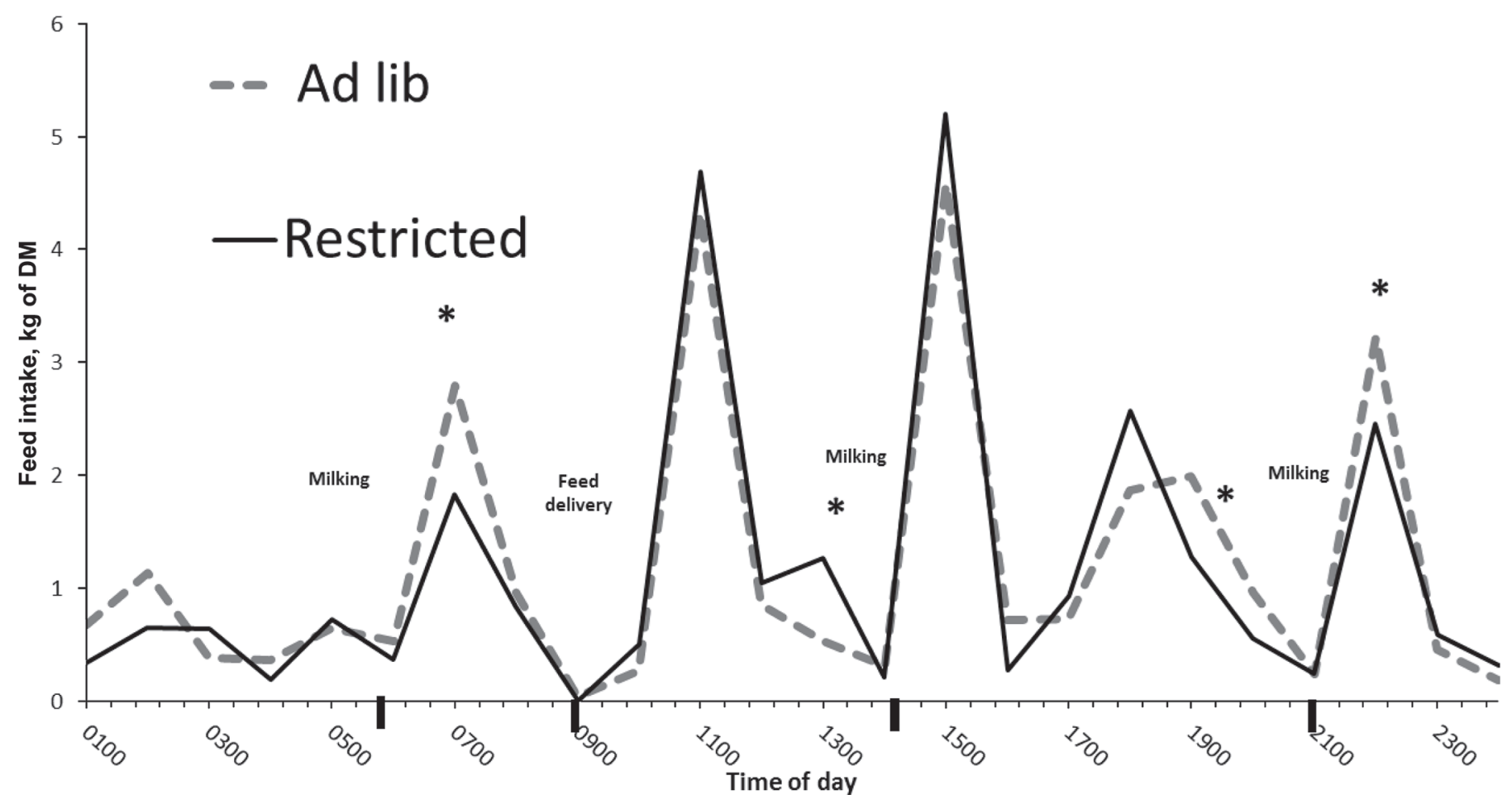

Figure 1. Diurnal feed intake of inefficient (INE) cows fed restricted versus cows fed ad libitum diet. Black rectangles mark time of external events indicated on graph. ${ }^{*}$ Significant difference $(P<0.05)$ between groups for each hour of the day.

\section{DISCUSSION}

The hypothesis of this study was that moderate feed restriction might improve efficiency of preclassified INE cows that eat above their energetic needs for production (Ben-Meir et al., 2018, 2019). This hypothesis was supported in a previous study by Cavallini et al. (2018) in which a $3.6 \%$ feed restriction of DMI to lactating cows fed a low-roughage TMR (34.5\% of DM) improved feed efficiency measured as ECM/DMI. Additional support for this hypothesis was provided by Wheelock et al. (2010) and Ferraretto et al. (2014), who reported that a restriction of $7.6 \%$ and $25 \%$ in ad libitum intake of dairy cows fed TMR containing $50 \%$ roughage led to an improvement in ECM/DMI. However, those feed restriction studies did not differentiate between preclassi-

Table 3. Comparison of in vivo digestibility, rumen $\mathrm{pH}$, rumination, and lying time of inefficient and efficient cows fed ad libitum versus those fed the restricted diet

\begin{tabular}{lccc}
\hline & \multicolumn{2}{c}{ Inefficient cows (means $\pm \mathrm{SE}$ ) } & \\
\cline { 2 - 3 } Component & Restricted & Ad libitum & P-value \\
\hline Number of cows & 12 & 12 & \\
In vivo digestibility, $\%$ & & & 0.90 \\
DM & $66.9 \pm 0.97$ & $67.0 \pm 1.09$ & 0.41 \\
NDF & $48.9 \pm 1.28$ & $47.4 \pm 1.19$ & 0.83 \\
OM & $68.9 \pm 0.96$ & $69.2 \pm 0.96$ & 0.98 \\
CP & $63.3 \pm 1.42$ & $63.3 \pm 1.54$ & 0.60 \\
Ether extract & $83.6 \pm 2.67$ & $82.8 \pm 4.75$ & 0.24 \\
NFC & $86.4 \pm 4.98$ & $88.7 \pm 3.97$ & 0.26 \\
Rumen pH am & $6.84 \pm 0.05$ & $6.72 \pm 0.09$ & 0.93 \\
Rumen pH pm & $6.49 \pm 0.07$ & $6.48 \pm 0.08$ & 0.08 \\
Rumination, min/d & $485 \pm 6.4$ & $499 \pm 4.9$ & 0.01 \\
Rumination, min/kg of DM & $18.3 \pm 0.23$ & $16.5 \pm 0.17$ & 0.01 \\
Lying, min/d & $562 \pm 5.0$ & $603 \pm 8.1$ & \\
\hline
\end{tabular}


fied INE and E cows, and they provided no information about the effects of feed restriction on eating behavior, RFI, and energy balance.

\section{Effects of Feed Restriction on Eating Behavior and Feed Efficiency of INE Cows}

In both dietary treatments, the social herd effect behavior of INE cows showed 4 to 5 meals (peaks) during the day and an additional 1 to 2 meals at night (Figure 1). In both dietary treatments of INE cows, the initiation of major meal peaks was triggered by external events, including feed delivery or returning from each milking (rectangles on timeline in Figure 1). A similar diurnal pattern of 6 to 7 meals in response to the same external events was found in our previous studies (Adin et al., 2009; Ben Meir et al., 2018, 2019), with cows fed ad libitum, and it reflected a social herd effect on meal initiation by each individual cow. Similar average numbers of 5.8 to $6.7 \mathrm{meal} / \mathrm{d}$ were also reported by Tolkamp et al. (2000), who demonstrated that for a variety of diets fed ad libitum, each of the 6 meals is composed of several visits with short intervals in between.

In the present study, regardless of dietary treatment, an average meal lasted $37.0 \mathrm{~min}$ (Table 2). We therefore suggest that the length of an average meal is constant in the range of 35 to $40 \mathrm{~min}$ before the physiological responses to absorbed nutrients (mainly propionate concentration in the liver vein) activate satiety in the brain to terminate the meal, as described by Allen and Bradford (2006) and Kokkinos et al. (2010). Therefore, the higher DMI of the ad libitum versus restricted INE cows fed the same diet was attributed to meal and visit frequency reflected in longer daily eating time rather than in eating rate and meal size (Table 2). A possible explanation for this finding could be that INE cows that consumed DMI above their energetic needs (Ben Meir et al., 2018) were less motivated for compensation under feed restriction.

\section{Effect of DMI on ECM Production of INE Cows}

In our previous study, in which we compared $\mathrm{E}$ and INE cows fed the same low-roughage diet ad libitum (Ben Meir et al., 2018), we found eating above energy needs, evident as higher HP and energy loss, to be the main reason for a lower efficiency of high-yielding INE cows, although ECM production was similar in both efficiency groups. The relationship between ECM and DMI of the whole herd in that study showed a diminishing response, with a -0.046 slope of ECM/DMI upon DMI, meaning that each unit of DMI reduced the ECM response. These findings are in accord with Moallem (2016), who reported a negative correlation ( $\mathrm{r}$ $=-0.5)$ between marginal efficiency (ECM/DMI) and DMI. Accordingly, data in the present study show that the reduction of $3.9 \mathrm{~kg}$ in DMI of INE cows fed the restricted diet led to only a $2-\mathrm{kg}$ reduction in their ECM yield compared with INE cows fed the ad libitum diet (Table 2). These findings indicate that feed intake of INE cows (either restricted or fed ad libitum) is within the same range in the diminishing response model.

\section{Effects of Feed Restriction on Efficiency, Energy Balance, Lying and Rumination Time, and Digestibility}

This study show that feed restriction that reduced DMI by $12.8 \%$ in INE cows improved efficiency in terms of RFI and ECM/DMI compared with cows fed ad libitum (Table 2). This outcome can be explained by the high reduction (20.5\%) in HP + energy losses

Table 4. Energy balance parameters of inefficient cows fed ad libitum versus cows fed restricted diet

\begin{tabular}{|c|c|c|c|}
\hline \multirow[b]{2}{*}{ Item $^{1}$} & \multicolumn{2}{|c|}{ Inefficient cows (means $\pm \mathrm{SE}$ ) } & \multirow[b]{2}{*}{$P$-value } \\
\hline & Restricted & Ad libitum & \\
\hline $\mathrm{N}$ & 12 & 12 & \\
\hline DE, Mcal $/ \mathrm{kg}$ of DM & $2.97 \pm 0.05$ & $2.98 \pm 0.05$ & 0.90 \\
\hline DEI, Mcal/d & $78.7 \pm 0.61$ & $90.6 \pm 0.84$ & 0.01 \\
\hline $\mathrm{NE}_{\mathrm{L}}, \mathrm{Mcal} / \mathrm{d}$ & $26.1 \pm 0.27$ & $28.1 \pm 0.28$ & 0.01 \\
\hline $\mathrm{NE}_{\mathrm{M}}, \mathrm{Mcal} / \mathrm{d}$ & $11.0 \pm 0.03$ & $10.80 \pm 0.05$ & 0.50 \\
\hline $\mathrm{NE}_{\mathrm{G}}, \mathrm{Mcal} / \mathrm{d}$ & $4.83 \pm 1.11$ & $5.36 \pm 1.05$ & 0.74 \\
\hline $\mathrm{NE}_{\mathrm{T}}, \mathrm{Mcal} / \mathrm{d}$ & $41.9 \pm 0.32$ & $44.3 \pm 0.24$ & 0.24 \\
\hline $\mathrm{NE}_{\mathrm{T}} / \mathrm{DEI}$ & $0.53 \pm 0.01$ & $0.49 \pm 0.01$ & 0.01 \\
\hline $\mathrm{NE}_{\mathrm{L}} / \mathrm{DEI}$ & $0.33 \pm 0.01$ & $0.31 \pm 0.01$ & 0.01 \\
\hline $\mathrm{HP}+$ energy loss, Mcal/d & $36.8 \pm 0.60$ & $46.3 \pm 0.80$ & 0.01 \\
\hline
\end{tabular}


and the low reduction of $2.4 \mathrm{Mcal} / \mathrm{d}$ in $\mathrm{NE}_{\mathrm{T}}$, leading to an $8.1 \%$ improvement in energetic efficiency in terms of $\mathrm{NE}_{\mathrm{T}} /$ DEI (Table 4).

The DMI restriction of $12.8 \%$ in INE cows did not affect in vivo DM digestibility. These results are in accordance with Cavallini et al. (2018), who reported that feed restriction of $3.6 \%$ did not affect digestibility. Notwithstanding, Ben Meir et al. (2018) reported lower digestibility (by 3 percentage units) of INE cows that ate $25 \%$ more DM of a low-roughage diet than E cows. This discrepancy between studies suggests that large differences in DMI of a low-roughage diet are needed to have a significant effect on digestibility.

\section{Commercial Implications of Feeding Restriction in INE and E Cows}

In the current study, INE cows fed a restricted diet reduced their daily DMI by $3.9 \mathrm{~kg}$, while their daily ECM yield declined by $2.0 \mathrm{~kg}$, compared with cows fed ad libitum. Under current Israeli conditions, where the daily price of milk is more than double the cost of daily TMR consumed, this practice of dietary restriction is questionable for INE cows.

\section{CONCLUSIONS}

A $12.8 \%$ feed restriction for cows that were preclassified as INE led to improved feed efficiency in terms of reduced RFI, increased ECM/DMI, and increased $\mathrm{NE}_{\mathrm{T}} / \mathrm{DEI}$ compared with INE cows fed ad libitum. Feed restriction increased feed efficiency for the INE cows, but it is not economically viable at current prices. Thus, further research is warranted to reduce the DMI of preclassified INE cows without causing a reduction in ECM yield.

\section{ACKNOWLEDGMENTS}

The authors express their appreciation to Yavne Feeding Center for the production of TMR and to the team at the ARO research dairy farm for their efforts. This study was supported by grant no. 362-0546 from the Israeli Dairy Board Foundation. The authors thank the Israeli Ministry of Agriculture and Rural Development for financial support (project number 4594514).

\section{REFERENCES}

Adin, G., R. Solomon, M. Nikbachat, A. Zenou, E. Yosef, A. Brosh, A. Shabtay, S. J. Mabjeesh, I. Halachmi, and J. Miron. 2009. Effect of feeding cows in early lactation with diets differing in roughageneutral detergent fiber content on intake behavior, rumination, and milk production. J. Dairy Sci. 92:3364-3373.
Allen, M. S., and B. J. Bradford. 2006. Metabolic regulation of food intake in ruminants. J. Anim. Sci. 84:120-121.

Asher, A., A. Shabtay, A. Haim, Y. Aharoni, J. Miron, G. Adin, A. Tamir, A. Arieli, I. Halachmi, U. Moallem, A. Orlov, and A. Brosh. 2014. Time required to determine performance variables and production efficiency of lactating dairy cows. J. Dairy Sci. 97:4340-4353.

AOAC. 1990. Official Methods of Analysis, Vol. 1. 15th ed. Association of Official Analytical Chemists, Arlington, VA.

Ben Meir, Y. A., M. Nikbachat, Y. Fortnik, S. Jacoby, H. Levit, G. Adin, M. Cohen Zinder, A. Shabtay, E. Gershon, M. Zachut, S. J. Mabjeesh, I. Halachmi, and J. Miron. 2018. Eating behavior, milk production, rumination and digestibility characteristics of high and low efficient lactating cows fed a low-roughage diet. J. Dairy Sci. 101:10973-10984.

Ben Meir, Y. A., M. Nikbachat, S. Jacoby, Y. Portnik, H. Levit, A. Kleinjan Elazary, E. Gershon, G. Adin, M. Cohen Zinder, A. Shabtay, M. Zachut, S. J. Mabjeesh, I. Halachmi, and J. Miron. 2019. Effect of lactation trimester and parity on eating behavior, milk production and efficiency traits of dairy cows. Animal 13:1736-1743. https://doi.org/10.1017/S1751731118003452.

Bloch, V., H. Levit, and I. Halachmi. 2019. Assessing the potential of photogrammetry to monitor feed intake of dairy cows. J. Dairy Res. 86:34-39.

Cavallini, D., M. E. Mammi, M. Fustini, A. Palmonari, A. J. Heinrichs, and A. Formigoni. 2018. Effect of ad libitum or restricted access to total mixed ration with supplemental long hay on production, intake and rumination. J. Dairy Sci. 101:10922-10928.

DeVries, T. J., M. A. G. von Keyserlingk, D. M. Weary, and K. A. Beauchemin. 2003. Measuring the feeding behavior of lactating dairy cows in early to peak lactation. J. Dairy Sci. 86:3354-3361.

Drissler, M., M. Gaworski, C. B. Tucker, and D. M. Weary. 2005. Free-stall maintenance: effects on lying behavior of dairy cattle. J. Dairy Sci. 88:2381-2387.

Ferraretto, L. F., H. Gencoglu, K. S. Hackbart, A. B. Nascimento, F. Dalla Costa, R. W. Bender, J. N. Guenther, R. D. Shaver, and M. C. Wiltbank. 2014. Effect of feed restriction on reproductive and metabolic hormones in dairy cows. J. Dairy Sci. 97:754-763.

Friggens, N., G. C. Emmans, S. Robertson, D. G. Chamberlain, C. T. Whittemore, and J. D. Oldham. 1995. The lactational responses of dairy cows to amount of feed and to the source of carbohydrate energy. J. Dairy Sci. 78:1734-1744.

Halachmi, I., Y. Edan, E. Maltz, U. M. Peiper, U. Moallem, and I. Brukental. 1998. A real-time control system for individual dairy cow food intake. Comput. Electron. Agric. 20:131-144.

Halachmi, I., M. Guarino, J. Bewley, and M. Pastell. 2019. Smart animal agriculture: Application of real-time sensors to improve animal well-being and production. Annu. Rev. Anim. Biosci. 7:403-425.

Kokkinos, A., C. W. Le Roux, K. Alexiadou, N. Tentolouris, R. P. Vincent, D. Kyriaki, D. Perrea, M. A. Ghatei, S. R. Bloom, and N. Katsilambros. 2010. Eating slowly increases the postprandial response of the anorexigenic gut hormones, peptide yy and glucagonlike peptide-1. J. Clin. Endocrinol. Metab. 95:333-337.

Kononoff, P. J., A. J. Heinrichs, and H. A. Lehman. 2003. The effect of corn silage particle size on eating behavior chewing activity, and rumen fermentation in lactating dairy cows. J. Dairy Sci. $86: 3343-3353$.

Lammers, B. P., D. R. Buckmaster, and A. J. Heinrichs. 1996. A simple method for the analysis of particle sizes of forage and total mixed rations. J. Dairy Sci. 79:922-928.

Moallem, U. 2016. Future consequences of decreasing marginal production efficiency in high-yielding dairy cow. J. Dairy Sci. 99:29862995.

NRC. 2001. Nutrient Requirements of Dairy Cattle. 7th rev. ed. Natl. Acad. Press, Washington, DC.

Potts, S. B., J. R. Boerman, A. L. Lock, M. S. Allen, and M. J. VandeHaar. 2015. Residual feed intake is repeatable for lactating Holstein dairy cows fed high and low starch diets. J. Dairy Sci. 98:4735-4747.

SAS Institute Inc. 2016. JMP ${ }^{\circledR} 13$ Fitting Linear Models. SAS Institute Inc., Cary, NC. 
Schirmann, K., M. A. G. von Keyserlingk, D. M. Weary, D. M. Veira, and W. Heuwieser. 2009. Technical note: Validation of a system for monitoring rumination in dairy cows. J. Dairy Sci. 92:6052-6055.

Shaani, Y., D. Eliyahu, I. Mizrahi, E. Yosef, Y. Ben-Meir, M. Nikbachat, R. Solomon, S. J. Mabjeesh, and J. Miron. 2016. Effect of feeding ensiled mixture of pomegranate pulp and drier feeds on digestibility and milk performance in dairy cows. J. Dairy Res. $83: 35-41$

Swartz, T. H., M. L. McGilliard, and C. S. Petersson-Wolfe. 2016 Technical note: The use of an accelerometer for measuring step activity and lying behaviors in dairy calves. J. Dairy Sci. 99:91099113.

Tilley, J. M. A., and R. A. Terry. 1963. A two-stage technique for the in vitro digestion of forage crops. J. Br. Grassl. Soc. 18:104-111.

Tolkamp, B. J., D. J. Allcroft, E. J. Austin, B. L. Nielsen, and I. Kyriazakis. 1998. Satiety splits feeding behaviour into bouts. J. Theor. Biol. 194:235-250.
Tolkamp, B. J., D. P. N. Schweitzer, and I. Kyriazakis. 2000. The biologically relevant unit for the analysis of short-term feeding behavior of dairy cows. J. Dairy Sci. 83:2057-2068.

Van Soest, P. J., J. B. Robertson, and B. A. Lewis. 1991. Methods for dietary fiber, neutral detergent fiber and non-starch polysaccharides in relation to animal nutrition. J. Dairy Sci. 74:3583-3597.

Weller, J. I., and E. Ezra. 2016. Genetic and phenotypic analysis of daily Israeli Holstein milk, fat, and protein production as determined by a real-time milk analyzer. J. Dairy Sci. 99:9782-9795.

Wheelock, J. B., R. P. Rhoads, M. J. VanBaale, S. R. Sanders, and L. H. Baumgard. 2010. Effects of heat stress on energetic metabolism in lactating Holstein cows. J. Dairy Sci. 93:644-655.

Xi, Y. M., F. Wu, D. Q. Zhao, Z. Yang, L. Li, Z. Y. Han, and G. L. Wang. 2016. Biological mechanisms related to differences in residual feed intake in dairy cows. Animal 10:1311-1318. 